\title{
Decentralization and Vertical Control in China's Government Controlled Firms
}

\author{
Yanfeng Jiang \\ Department of Public Economics University of Xiamen, Xiamen 361005, China \\ Jiangyanfeng2011@126.com
}

\begin{abstract}
China's government controlled firms face two conflict tasks: For one thing, government should credibly delegate efficiency to firms to make them competitive. For the other, the government also needs to control the firms to achieve their political goals. We suggest one way in which the China's government solves this conflict tasks by building pyramidal business groups in which they delegate authority while simultaneously creating vertical correlations to maintain control. Further, we theorize that higher levels of government are more likely to pursue this strategy. Results of quantitative analysis of China's government controlled business groups generally support our expectations.
\end{abstract}

Index Terms - China's government controlled firms, decentralization, vertical control.

\section{Introduction}

How does China's government solve the corporate governance challenge of on the one hand delegating managerial responsibility to firms and on the other maintaining control? Are there differences in how government does that depending on whether it is central, regional or local government? This paper focuses on these questions, and analyses government controlled pyramidal business groups in China. Extensive government ownership of private firms is a characteristic of many emerging economies including China. Studies suggest, however, that government ownership is likely to be detrimental to firm performance as governments are likely to be tempted to use firms to pursue objectives are not aligned with business priorities. To mitigate this problem, government can seek to insulate firms to minimize the temptation to interfere. This objective can, for instance, be achieved by developing layered ownership structures that create distance between the government and the firm (Lee and Jin, 2009) [1].While it opens up for another set of challenges, namely how to maintain control and avoid agency costs.

The organization structures of China's government controlled firms have received considerable attention in recent years, yet how different branches and levels of government are involved in business in China in different ways is not systematically studied and there is very little literature that directly compares different levels of government and analyses different strategies for the development and governance of government firms depending on level of government. This article addresses issues related to this gap. The main topic is governance of state controlled business groups. We propose that vertical correlations constitute a solution to the challenge of securing control of business to which governments has delegated a large amount of control.

\section{Problem Formulation}

Studies in China and elsewhere have found that the benefits of business group affiliation are reduced as market institutions (Carney et al., 2011[2], Keister,2001[3]). However, in spite of institutional development, China's state owned business groups have generally demonstrated good performance (Carney et al., 2009 [4], Guest and Sutherland, 2010[5], Yu et al., 2009[6]). Following from that, it has been argued that business groups in China have been used as organizational devices by the government to create growth by fostering decentralization and managerial autonomy (Lee and Jin,2009[1]).It follows from this that institutional development is not a determinant of these groups' performance (Seo et al.,2010[7]).

Pyramidal business groups are often associated with family ownership (Riyanto and Toolsema, 2008[8]).In China however, there is a prevalence of state owned business groups with pyramid structures (Seo et al., 2010 [7]).A pyramid structure can provide the financial resources for investment in new firms (Almeida and Wolfenzon, 2006[9]) and otherwise provide the coordination and resources needed to reduced transactions costs (Riyanto and Toolsema, 2008[8]). Another explanation focuses on agency problems: Weak institutional frameworks create incentives for the creation of pyramids (Baek et al., 2006[10]).

The apex firm of the pyramid has strong incentives to divert resources above and beyond their formal cash flow rights, from firms further down the pyramid, and that is a phenomenon known as tunneling. This incentive is due to the ultimate owner has direct and indirect control rights of firms in the pyramid but often with very limited cash flow rights. Consequently, the controller engage in different types of tunneling activities in order to exploit its controlling position (Riyanto and Toolsema, 2008[8]).

Based on the discussion above, it reasonable to expect different levels of government to pursue different corporate governance strategies in relation to the business groups they control. Fan and colleagues (2012) [11] investigated how local governments forms pyramidal business groups. To our knowledge no studies have investigated how the strategy varies between different levels of government. According to theories of information costs, there should be a greater incentive to delegate the greater the benefits of local information (Mookherjee,2006 [12]). China's government organizations at both central, provincial and municipal are controlling business groups. Accordingly, we expect the 
central government to have the greatest incentives to use pyramidal layers to delegate.

Hypothesis 1: The higher the level of government controlling a business group, the more layers are likely to be developed between the apex and a given listed firm.

The discussion above about agency problems in pyramidal business group configurations and vertical correlations as possible response directs attention to two situations in which a business group apex would seek to form a correlation: First, when it wants to generate a basis for transferring value out of an affiliated firm. Second, when it wants to effectively monitor a firm. The incentive for transferring assets between firms increases when the divergence between cash flow rights and control rights of the apex firm is higher. For government controlled business groups, such incentives may interact with political motives. Hence we arrive at the following hypothesis:

Hypothesis 2: A vertical correlations between apex firm and listed affiliated firm is more likely to exist when the difference between cashflow rights and control rights of the apex firm is large.

Layering (ties between apex firm and firms further down the pyramidal structure), it is stipulated in the literature, is a decentralizing device which also increase traditional agency problems associated with monitoring agents in lower level firms(Fan et al., 2012[15]). We have here theorized that vertical correlations are a response to agency problems. It follows from this that correlations are more likely to exist in pyramids with a high number of layers. Therefore:

Hypothesis 3: A vertical correlation between apex firm and listed affiliated firm is more likely to exist when the number of layers between a listed firm and its business group apex is higher.

Now we turn to the question of how government level may impact the likelihood of a vertical correlation exists. According to theories of information costs, there should be a greater incentive to delegate when the benefits of local information is greater (Mookherjee, 2006[12]). Higher levels of government should have greater incentives to maintain control through vertical correlations than lower levels of government. Therefore:

Hypothesis 4: A vertical correlation between apex firm and listed affiliated firm is more likely to exist when a business group is controlled by higher levels of government than lower levels of government.

We begin by analyzing differences in how the listed affiliated firms (henceforth affiliated firms) are controlled, depending on which level of government controls them. The main part of our analysis focuses on vertical correlations, which we show is a means to limit agency problems. We argue that the level of government controlling the business group translates into a variation of the extent to which such correlations are used.

\section{Problem Solution}

A. Method

To investigate layering and vertical correlations of government controlled business groups we focus on China's listed firms affiliated with a business group. This is an excellent setting as government controlled business groups are a dominant feature of China's industry structure. Importantly, China's business groups are controlled by governments at different levels ranging from central government through provincial government to municipal government. We chose to focus on listed firms as unit of analysis as this enables us to assess the existence of a vertical correlation while simultaneously control a number of firm specific factors which may confound the influences of a variables of interest.

We use data from a range of different sources. Financial data of listed firms was obtained from the Wind database. We used the background descriptions of executives in annual reports, and information about the control chain of business groups was collected from annual reports.

In total we have data for 3085 firm-year observations in the period 2007-2010. Our data set contains all listed firms affiliated with state owned pyramidal business groups except for those firms that are affiliated with a business groups controlled directly by SASAC without an apex firm.

\section{B. Variables}

Our two dependent variables are number of pyramidal layers and vertical correlations. Layering is measured simply as the number of entities existing between a business group apex and a given listed firm in our sample. This measurement of layering has been used in previous research (Fan et al., 2012[15]). The average number of layers between the listed firms in our sample and their respective apex firms is 3.64. Vertical correlations exist when the chairman of the board of a listed firm also holds an influential position in the business group apex. No less than $71 \%$ of the board chairmen of the listed firms are connected to the apex through a vertical correlation. We choose to focus on the chairman of the board because of this person's typically pervasive involvement in business activities and role as the main executive of China's firms. Based on our hand-collected data we construct three dummy variables indicating different types of vertical correlation indicating the level of the position a chairman concurrently holds in the apex. We estimate separate models for these as we have no prior expectation to which type of correlation might be the most important. The dummy variable Chair 1 is equal to 1 if the correlating position of affiliated chairman is higher or equal to divisional manager level in the apex firm, and 0 otherwise; Chair2 is equal to 1 if the correlating position of affiliated chairman is higher or equal to vice general manager level in business group, and 0 otherwise; Chair3 is equal to 1 if the correlating position of affiliated chairman is higher or equal to general manager level in business group, and 0 otherwise. This means that the variables are indicating the hierarchical position in the apex with Chair1<Chair2<Chair3.

The first main independent variable is the level of the government controlling the business group. We measure this by use of dummy variables for central, provincial and municipal government control.

Our other main independent variable is "controlcash" 
which is a measure of divergence between voting rights and cash flow rights of the ultimate controller, defined as the largest shareholding in percent minus the percent of cash flow rights owned by the ultimate controller. A higher value of this variable indicates a higher incentive for business group apex firm to seek to divert resources away from the listed firm. Control rights can be higher than the cash flow rights because of the nested ownership structures of pyramidal business groups. The apex firm may have little formal cash flow rights of firms low in the pyramid but high controlling rights because it has ownership of firms between the listed firm and itself.

We include a number of control variables in the analyses. We include measures of firm size age, ROA, risk, leverage, size of largest shareholder, CEO duality and board size, which may impact our focal relations. We also include the NERI index of marketization of China's provinces, this indicates the degree of market development in the home province of the listed firm, and it is an important control because market development may mitigate agency problems and make vertical correlations superfluous.

We estimate the degree of layering using OLS regression. The existence of a correlation is estimated by using logistic regressions.

\section{Results}

TABLE1 reports the results of the regression analysis with number of layers as dependent variable. In model 2 and 3 two dummy variables are entered indicating central government control and provincial government control respectively (municipality government is the omitted category). With positive and significant coefficients the results lend support to hypothesis 1.Central government controlled groups indeed are likely to develop more layers than the two remaining groups. Further, provincial government controlled groups are more likely to do so than the municipal controlled ones.

TABLE 1 Regression Predicting the Number of Layers between a Listed Firm and Its Business Group Apex Firm

\begin{tabular}{|c|c|c|c|}
\hline & (1) & (2) & (3) \\
\hline Index & $0.051 * * *(5.47)$ & $0.049 * * *(5.51)$ & $0.056^{* * *}(6.27)$ \\
\hline Controlcash & $4.739 * * *(22.25)$ & $4.281 * * *(19.75)$ & $4.301 * * *(21.23)$ \\
\hline Size & $-0.038 * *(-2.52)$ & $-0.076 * * *(-4.89)$ & $-0.082 * * *(-5.44)$ \\
\hline ROA & $-0.159(-0.59)$ & $-0.087(-0.39)$ & $-0.123(-0.48)$ \\
\hline Risk & $0.0038(0.045)$ & $-0.0038(-0.46)$ & $-0.0069(-0.85)$ \\
\hline Leverage & $-0.027(-0.30)$ & $0.033(0.37)$ & $0.068(0.75)$ \\
\hline Top & $-0.539 * * *(-4.53)$ & $-0.455 * * *(-4.03)$ & $-0.536 * * *(-4.77)$ \\
\hline Age & $0.0029(0.63)$ & $0.0109 * *(2.54)$ & $0.0087 * *(2.09)$ \\
\hline CEO duality & $-0.023(-0.41)$ & $-0.001(-0.19)$ & $0.055(1.08)$ \\
\hline Board size & $0.021 * * *(2.68)$ & $0.020 * * *(2.71)$ & $0.018 * * *(2.55)$ \\
\hline $\begin{array}{c}\text { Central } \\
\text { Government } \\
\text { Owner }\end{array}$ & & $0.621 * * *(17.86)$ & $0.760 * * *(18.88)$ \\
\hline $\begin{array}{c}\text { Provincila } \\
\text { Government } \\
\text { Owner }\end{array}$ & & & $0.262 * * *(6.62)$ \\
\hline Constant & $3.633 * * *(10.35)$ & $4.235 * * *(12.60)$ & $4.256^{* * * *}(12.81)$ \\
\hline $\operatorname{Adj} R^{2}$ & 0.1883 & 0.2601 & 0.2682 \\
\hline
\end{tabular}

$* * *) \mathrm{p}<0.001 ; * *) \mathrm{p}<0.01 ; *) \mathrm{p}<0.05$
Next we turn to the existence of vertical correlations. Hypothesis 2 states that correlations are more likely when the difference between control rights and cash flow rights (the variable "controlcash") is larger. Hypothesis 3 states that correlations are more likely in groups with more layers. This is tested in TABLE2 below.

TABLE 2 Vertical Correlations between Listed Firms and Business Group Apex Firms.

\begin{tabular}{|c|c|c|c|}
\hline & $(1)$ Chair1 & (2) Chair2 & $(3)$ Chair3 \\
\hline $\begin{array}{c}\text { Number of } \\
\text { layers }\end{array}$ & $0.118^{* *}(2.36)$ & $0.107^{* *}(2.19)$ & $-0.016(-0.37)$ \\
\hline Controlcash & $1.886^{* * *}(2.85)$ & $2.033^{* * *}(3.16)$ & $0.318(0.58)$ \\
\hline Size & $0.175^{* * *}(3.78)$ & $0.218^{* * *}(4.68)$ & $0.276^{* * *}(6.69)$ \\
\hline ROA & $2.388^{* * *}(3.43)$ & $2.548^{* * *}(3.78)$ & $0.621(0.99)$ \\
\hline Risk & $0.041^{*}(1.73)$ & $0.032(1.36)$ & $0.001(0.038)$ \\
\hline Leverage & $0.433^{*}(1.70)$ & $0.378(1.56)$ & $-0.102(-0.45)$ \\
\hline Top & $1.476^{* * *}(4.59)$ & $1.185^{* * *}(3.81)$ & $1.678^{* * *}(5.88)$ \\
\hline Age & $0.027 * *(2.26)$ & $0.023 * *(2.07)$ & $0.039 * * *(3.46)$ \\
\hline CEO duality & $-1.268^{* * *}(-9.51)$ & $-1.117 * * *(-8.47)$ & $-1.122 * * *(-7.53)$ \\
\hline Board size & $0.016(0.68)$ & $0.011(0.44)$ & $0.025(1.23)$ \\
\hline Index & $0.052^{* *}(2.03)$ & $0.032(1.26)$ & $-0.025(-1.00)$ \\
\hline Constant & $-5.866^{* * *}(-5.89)$ & $-6.279 * * *(-6.48)$ & $7.191 * * *(-8.19)$ \\
\hline Adj $\boldsymbol{R}^{2}$ & 0.084 & 0.081 & 0.074 \\
\hline
\end{tabular}

$* * *) \mathrm{p}<0.001 ; * *) \mathrm{p}<0.01 ; *) \mathrm{p}<0.05$

Dependent variable Chair1 is equal to 1 if the interlocking position of affiliated chairman is higher or equal to divisional manager level in the apex firm, and 0 otherwise; Chair 2 is equal to 1 if the interlocking position of affiliated chairman is higher or equal to vice general manager level in business group, and 0 otherwise; Chair 3 is equal to 1 if the interlocking position of affiliated chairman is higher or equal to general manager level in business group, and 0 otherwise.

Three models are presented each with a separate dependent variable indicating the hierarchical position a chairman holds in the apex firm. Model 1 and 2 suggest support for the hypotheses as controlcash and number of layers are both positively and significant related to the existence of an correlation .There is no support in model 3.This indicates that correlations are associated with controlcash and layering, but the effect disappears in the cases where ties are formed to the very highest levels of the apex firms.

Next we turn to the role of government control in determining vertical correlations. 
TABLE 3 Vertical Correlations between Listed Firms and Business Group Apex Firms.

\begin{tabular}{|c|c|c|c|}
\hline & (1) Chair1 & (2) Chair2 & (3) Chair3 \\
\hline $\begin{array}{c}\text { Government Level } \\
\text { (1=central; } 2=\text { prov; } \\
3=\text { local) }\end{array}$ & $\begin{array}{l}-0.032 \\
(-0.55)\end{array}$ & $\begin{array}{c}-0.176 * * * \\
(-3.44)\end{array}$ & $\begin{array}{c}-0.295 * * * \\
(-5.50)\end{array}$ \\
\hline $\begin{array}{c}\text { Number of } \\
\text { Layers }\end{array}$ & $\begin{array}{c}0.130^{* * *} \\
(2.42)\end{array}$ & $\begin{array}{c}0.159^{* * * *} \\
(3.03)\end{array}$ & $\begin{array}{l}0.065 \\
(1.43)\end{array}$ \\
\hline Controlcash & $\begin{array}{c}1.891 * * * \\
(2.86)\end{array}$ & $\begin{array}{c}1.994 * * * \\
(3.11)\end{array}$ & $\begin{array}{l}0.221 \\
(0.39)\end{array}$ \\
\hline Size & $\begin{array}{c}0.180^{* *} \\
(3.87)\end{array}$ & $\begin{array}{c}0.232 * * * \\
(5.12)\end{array}$ & $\begin{array}{l}0.317 * * * \\
(7.83)\end{array}$ \\
\hline ROA & $\begin{array}{c}2.392 * * * \\
(3.43)\end{array}$ & $\begin{array}{c}2.572 * * * \\
(3.81)\end{array}$ & $\begin{array}{l}0.618 \\
(1.01)\end{array}$ \\
\hline Risk & $\begin{array}{c}0.041^{*} \\
(1.79)\end{array}$ & $\begin{array}{l}0.037 \\
(1.63)\end{array}$ & $\begin{array}{l}0.010 \\
(0.48)\end{array}$ \\
\hline Leverage & $\begin{array}{c}0.425^{*} \\
(1.66)\end{array}$ & $\begin{array}{l}0.331 \\
(1.35)\end{array}$ & $\begin{array}{l}-0.187 \\
(-0.82)\end{array}$ \\
\hline Top & $\begin{array}{c}1.483 * * * \\
(4.59)\end{array}$ & $\begin{array}{c}1.226 * * * \\
(3.93)\end{array}$ & $\begin{array}{c}1.787 * * * \\
(6.29)\end{array}$ \\
\hline Age & $\begin{array}{c}0.027 * * \\
(2.20)\end{array}$ & $\begin{array}{c}0.022^{*} \\
(1.89)\end{array}$ & $\begin{array}{c}0.034 * * * \\
(3.19)\end{array}$ \\
\hline CEO duality & $\begin{array}{c}-1.281 * * * \\
(-9.49)\end{array}$ & $\begin{array}{c}-1.180 * * * \\
(-8.80)\end{array}$ & $\begin{array}{c}-1.213 * * * \\
(-8.11)\end{array}$ \\
\hline Board size & $\begin{array}{l}0.015 \\
(0.69) \\
\end{array}$ & $\begin{array}{l}0.011 \\
(0.44) \\
\end{array}$ & $\begin{array}{l}0.026 \\
(1.25) \\
\end{array}$ \\
\hline Index & $\begin{array}{c}0.049 * * \\
(1.96)\end{array}$ & $\begin{array}{l}0.023 \\
(1.01)\end{array}$ & $\begin{array}{l}-0.033 \\
(-1.49) \\
\end{array}$ \\
\hline Constant & $\begin{array}{c}-5.906 * * * \\
(-5.93) \\
\end{array}$ & $\begin{array}{c}-6.517 * * * \\
(-6.68) \\
\end{array}$ & $\begin{array}{c}-7.720 * * * \\
(-8.77) \\
\end{array}$ \\
\hline Adj $R^{2}$ & 0.085 & 0.083 & 0.082 \\
\hline
\end{tabular}

***) $\mathrm{p}<0.001 ; * *) \mathrm{p}<0.01 ; *) \mathrm{p}<0.05$

Models 1-3 present direct relation between government level and correlations (hypotheses 4)

In total, the results strongly point to differences in how different levels of government exercise control over their business groups. Higher levels of government appear to be prone to delegation through the formation of a deeper pyramid. On the other hand, they also appear to be more likely to develop vertical correlations to mitigate agency problems.

\section{Conclusions}

Our study has provided insights into one way in which the China's government attempts to both delegate in order to reduce political costs yet also maintain control. Our results show, however, that one must be careful talking about China's government in singular. We find systematic differences due to level of government in our study. This difference, we argue, is due to distance, indicating that the central government faces greater challenges in retaining control over firms. The response of the central government is to create interlocking ties to ensure information and control.

The article contributes to the existing literature in three ways. Firstly, it provides a picture of a so far non-described method used by the China's government to tackle the dilemma of creating credible decentralization to businesses it controls while simultaneously maintaining a degree of control. Secondly, it provides a view of differences in organization and strategy of businesses control due to different levels of government in China. Thirdly, while there is a bourgeoning literature on correlation, but is almost exclusively horizontal links between independent firms, vertical correlations and correlations within business groups are much less analyzed, and the article shed lights on vertically correlating directories.

\section{References}

[1] Lee, K. and Jin, X., "The origins of business groups in China: An empirical testing of the three paths and the three theories", Business History, Vol.51, 2009, pp: 77-99.

[2] Garney, M., et al., "Business Groups, Affiliation, Performance, Context and Strategy: A Meta Analysis”, Academy of Management Journal, Vol.54, 2011, pp: 437-460.

[3] Keister, L.A., "Exchange structures in transition: Lending and trade relations in Chinese business groups", American Sociological Review, Vol.66, 2001, pp: 336-360.

[4] Carney, M., et al., "Business Group Performance in China: Ownership and Temporal Considerations", Management \& Organization Review, Vol.5, 2009, pp: 167-193.

[5] Guest, P. and Sutherland, D., "The impact of business group affiliation on performance: evidence from China's national champions", Cambridge Journal of Economics, Vol. 34, 2010, pp: 617-631.

[6] Yu, H., et al., "Does Group Affiliation Improve Firm Performance? The Case of Chinese State-Owned Firms", Journal of Development Studies, Vol.10, 2009, pp: 1615-1632.

[7] Seo, B.-K., et al., "Causes for changing performance of the business groups in a transition economy: market-level versus firm-level factors in China", Industrial \& Corporate Change, Vol.19, 2010, pp: 2041-2072.

[8] Riyanto, Y. E. and Toolsema, L. A., "Tunneling and propping: A justification for pyramidal ownership", Journal of Banking \& Finance, Vol.32, 2008, pp: 2178-2187.

[9] Almeida, H.V. and Wolfenzon, D., "A Theory of Pyramidal Ownership and Family Business Groups", Journal of Finance, Vol.61, 2006, pp: 2637-2680.

[10] Baek, J.-S., ET AL., "Business Groups and Tunneling: Evidence from Private Securities Offerings by Korean Chaebols", Journal of Finance, Vol.61, 2006, pp: 2415-2449.

[11] Fan, J. P. H., et al., "Institutions and organizational Structure: The Case of State Owned Corporate Pyramids", Journal of Law, Economics, and Organization, Vol.62, 2012, pp: 254-273.

[12] Mookherjee, D., "Decentralization, Hierarchies, and Incentives: A Mechanism Design Perspective", Journal of Economic literature, Vol.2, 2006, pp: 267-390. 